\title{
Prior Academic Achievement, Effort, and Achievement Goal Orientations: A Longitudinal Examination
}

\author{
Huy P. Phan ${ }^{1}$ \\ ${ }^{1}$ School of Education, The University of New England, Armidale, Australia \\ Correspondence: Huy P. Phan, School of Education, The University of New England, Armidale NSW, 2351, \\ Australia. Tel: 61-2-6773-3327. E-mail: hphan2@une.edu.au
}

Received: April 24, 2012

Accepted: June 28, $2012 \quad$ Online Published: August 3, 2012

doi:10.5539/jedp.v2n2p57

URL: http://dx.doi.org/10.5539/jedp.v2n2p57

\begin{abstract}
Empirical research has provided evidence attesting to the potency of two major theoretical frameworks in teaching and learning, namely, achievement goals and effort. The testing of achievement goals and effort in various cross-sectional studies (Dupeyrat \& Mariné, 2005; Elliot, McGregor, \& Gable, 1999; Fenollar, Román, \& Cuestas, 2007) has yielded findings that indicate their positive effects on academic achievement, directly and indirectly via means of other internal cognitive processes. We used latent growth modeling (LGM) procedures to identify and trace the initial states and change in mastery and performance-approach goals, and how they influence academic achievement in mathematics over time. Furthermore, aligning closely to social cognitive theory (Bandura, 1986, 1997), we explore the effects of prior academic achievement and effort on achievement goals and mathematic achievement. This examination involved 234 university students ( 97 females, 137 males) across six time points: prior academic achievement at Time 1, effort at Time 2, mastery and performance-approach goals at Time 3 to Time 5, and mathematic achievement at Time 6. Existing Likert-scale inventories were used to measure effort, mastery and performance-approach goals. Our LGM analyses indicated a decline in mastery goals and an increase in performance-approach goals over time. Both effort and prior academic achievement influenced the initial states of mastery and performance-approach goals, respectively. Likewise, prior academic achievement and effort contributed to the prediction of mathematic achievement at Time 6.
\end{abstract}

Keywords: prior academic achievement, effort, achievement goals, longitudinal examination

\section{Introduction}

Research in cognition and motivation has recently involved the study of the rate of change of both cognitive (e.g., achievement goal orientation) and non-cognitive (e.g., self-efficacy) processes. Researchers have, for example, used growth curve modeling procedures (Bollen \& Curran, 2006; Duncan, Duncan, Strycker, Li, \& Alpert, 1999; Hancock \& Lawrence, 2006; McArdle \& Nesselroade, 2003) to trace differing developmental trajectories of individuals' self-efficacy beliefs in educational (Caprara et al., 2008; Phan, 2011, 2012) and non-educational settings (Kim \& Cicchetti, 2006; Odgers et al., 2009). In essence, differing from other cross-sectional and longitudinal procedures (e.g., cross-lagged panel), this methodological approach is advantageous as it enables longitudinal examination of developmental changes of theoretical constructs and achievement outcomes. From this impetus, we incorporate LGM procedures in our research investigation to explore the developmental course of university students' mastery and performance-approach goal orientations over a two-year period. Furthermore, we regressed prior academic achievement and effort, as possible antecedents, onto academic achievement in mathematics and the initial states and change in mastery and performance-approach goals.

\subsection{A Conceptual Framework: Prior Academic Experience, Effort, and Mastery Goals}

The conceptual model that we have developed for this research investigation, as shown in Figure 1, arises from two major theoretical frameworks, namely, achievement goals and effort. Specifically, in conjunction with existing empirical evidence, our conceptual model emphasizes two major hypotheses: (i) the impact of prior academic achievement on students' effort, mastery and performance-approach goal orientations, and academic achievement, and (ii) the relations between effort and academic achievement, and between effort and the initial states and change in mastery and performance-approach goals and academic achievement. We purposively chose to examine effort and mastery and performance-approach goal orientations as these theoretical constructs have 
been shown to exert positive effects on academic achievement and related outcomes (Dupeyrat \& Mariné, 2005; Elliot et al., 1999; Liem, Lau, \& Nie, 2008; Phan, 2010b).

\subsection{Achievement Goals Framework}

Achievement goals theory, in its simplistic form, refers to the various differential influences of goals on students' academic learning via means of cognitive self-regulation processes (Covington, 2000). Cognitive self-regulation processes in this case emphasize learners' ability to actively engage in their own learning, and involve facets such as planning, organization, mobilizing resources to meet demands, and monitoring progress toward the completion of assignments. Recognizing that individuals vary in their patterns of cognition and behaviors, researchers have conceptualized and researched different models of achievement goals in various educational contexts and levels, namely, the dichotomous model (Elliott \& Dweck, 1988), the trichotomous model (Elliot, 1999; Elliot \& Church, 1997; Elliot \& Harackiewicz, 1996), the $2 \times 2$ model (Elliot \& McGregor, 2001), and the multiple-goals model (Harackiewicz, Barron, Pintrich, Elliot, \& Trash, 2002; Harackiewicz, Barron, Tauer, \& Elliot, 2002; Valle et al., 2003).

The different conceptualized models of achievement goals have been validated, empirically, and there is, to an extent, relatively consistent evidence, emphasizing key characteristics and nature of each achievement goal type. The simplistic model of achievement goals, the dichotomous model (Dweck \& Leggett, 1988; Nicholls, 1984; Wolters, Yu, \& Pintrich, 1996), entails two major goal types: mastery and performance. The trichotomous model, differing from the dichotomous model, acknowledges the performance goal construct differentiating into two separate goal entities: an avoidance goal orientation that focuses on individuals avoiding negative possibilities (e.g., failure or looking incompetent, normatively), and an approach goal orientation that focuses on individuals acquiring positive possibilities (e.g., attaining competence and demonstrating superiority) (Elliot \& Harackiewicz, 1996; Harackiewicz, Barron, Pintrich, et al., 2002; Van Yperen, Elliot, \& Anseel, 2009). The distinction between these three types of goals may be explained in the context of students' learning. A mastery goal orientation, for example, details the acquiring of new skills and students' major emphasis towards self-improvement of competence. A performance-approach goal orientation, in contrast, refers to students striving to demonstrate normatively high ability (e.g., "I want to do better than other students in my classes": Midgley et al., 1998), whereas a performance-avoidance goal emphasizes an avoidance of normative incompetence (e.g., "It's very important to me that I don't look stupid in my classes": Midgley et al., 1998). More recently, empirical research, albeit limited, has lent support for the bifurcation of the mastery goal construct into separate approach and avoidance goals, hence, the coining of the $2 \times 2$ theoretical model (Elliot, 1999; Elliot \& McGregor, 2001). For the $2 \times 2$ achievement goal model, a mastery-approach goal orientation emphasizes on the attainment of task-based or intrapersonal standards of competence, whereas a mastery-avoidance goal orientation focuses on one attempting to avoid task-based or intrapersonal standards of incompetence. Apart from the $2 \times 2$ orientation, the multiple goals, multiple pathways perspective (Pintrich, 2000; Pintrich, Conley, \& Kempler, 2003) also offers a tantalizing insight into the possible trajectories that students may adopt in their learning.

The achievement goals framework, notably, the trichotomous model, has been researched extensively in various educational contexts. There is substantial experimental and correlational research by Elliot and colleagues to show and validate the distinctiveness of mastery, performance-approach, and performance-avoidance goal orientations (Church, Elliot, \& Gable, 2001; Elliot et al., 1999; Elliot, Shell, Henry, \& Maier, 2005; Pekrun, Elliot, \& Maier, 2009). Unlike the trichotomous model of achievement goals, research involving the $2 \times 2$ model has been limited (Elliot \& McGregor, 2001; Elliot \& Murayama, 2008; Van Yperen et al., 2009) and, consequently, some researchers have even questioned its validity and/or inclusion (Deshon \& Gillespie, 2005). The is evidence to illuminate, in part, distinctive patterns in relation to achievement goals and cognitive strategies, motives, self-beliefs, and academic performance outcomes (see, for example, Pekrun et al., 2009). The potency of the trichotomous model of achievement goals is reflected, for example, by close associations between a mastery goal orientation and a myriad of positive behaviors, such as a preference for challenging work (Ames \& Archer, 1988; Elliott \& Dweck, 1988), persistence (Elliott \& Dweck, 1988), intrinsic motivation for learning (Meece, Blumenfeld, \& Hoyle, 1988; Stipek \& Kowalski, 1989), the use of deep processing strategies (Ames \& Archer, 1988; Dupeyrat \& Mariné, 2005; Fenollar et al., 2007; Liem et al., 2008; Meece et al., 1988; Nolen \& Haladyns, 1990; Senko \& Miles, 2008), reflection (Phan, 2009b), and effort expenditure (Chouinard, Karsenti, \& Roy, 2007; Fenollar et al., 2007). Similarly, from a social cognitive perspective (Bandura, 1986, 1997), mastery goals also relate positively with personal self-efficacy (Fenollar et al., 2007; Greene, Miller, Crowson, Duke, \& Akey, 2004; Liem et al., 2008). In this analysis, individuals who are self-efficacious in their learning of a subject matter are more inclined towards a mastery goal orientation. 
Empirical research studies have also reported findings that indicate close associations between performance-approach goals and adapting learning behaviors, such as higher aspiration, absorption during task engagement and performance attainment (Elliot et al., 1999), and the adoption of surface cognitive strategies (Dupeyrat \& Mariné, 2005; Fenollar et al., 2007; Phan, 2010b; Simons, Dewitte, \& Lens, 2004). Similarly, there is evidence to show that performance-avoidance goals are related negatively with intrinsic motivation (Elliot \& Harackiewicz, 1996), self-efficacy beliefs (Fenollar et al., 2007; Liem et al., 2008), and peer relationship (Liem et al., 2008), and positively with learned hopelessness (Phan, 2010b), task engagement (Liem et al., 2008), and effort expenditure (Fenollar et al., 2007). Furthermore, individuals adopting performance-avoidance goals are more disorganized in their study habits (Elliot et al., 1999; Senko \& Miles, 2008), and demonstrate more preference for the adoption of surface cognitive strategies (Liem et al., 2008; Phan, 2009c; Simons et al., 2004).

Research underpinning the trichotomous model of achievement goals has also reported evidence that accentuates the relations between mastery, performance-approach, and performance-avoidance goals and academic performance. Correlational analyses within the framework of structural equation modeling (SEM) have yielded findings showing the positive effect of mastery goals on academic performance (Tanaka \& Yamauchi, 2001; Vansteenkiste, Simons, Lens, Soenens, \& Matos, 2004). Similarly, academic performance is associated positively with students' orientation of performance-approach goals (Church et al., 2001; Durik, Lovejoy, \& Johnson, 2009; Senko \& Miles, 2008; Wolters, 2004), and negatively with performance-avoidance goals (Durik et al., 2009; Elliot et al., 1999).

\subsection{Effort as a Study Strategy}

Effort expenditure, although not as extensive as achievement goals in research development, has also been acknowledged to feature prominently in students' learning in achievement contexts (Cole, Bergin, \& Whittaker, 2008; Dupeyrat \& Mariné, 2005; Elliot et al., 1999; Fenollar et al., 2007; Simons et al., 2004). Effort refers to the overall amount of effort expended in the process of studying (Zimmerman \& Risemberg, 1997). Whilst not necessarily making a direct influence on students' academic achievement, effort has been found to relate positively with other cognitive-motivational constructs - for example, interest and importance (Cole et al., 2008), class size (Fenollar et al., 2007), competence beliefs (Chouinard et al., 2007), and mastery goal (Chouinard et al., 2007; Dupeyrat \& Mariné, 2005; Phan, 2009a; Simons et al., 2004) and performance-approach goal (Chouinard et al., 2007; Fenollar et al., 2007; Phan, 2009a) orientations.

\subsection{Examination of Prior Achievement, Effort, and Achievement Goals}

Drawing from the empirical literature, we decided to advance the study of effort and achievement goal orientations by incorporating these two theoretical orientations within one longitudinal model for examination. Uniquely characteristic, we hypothesized a number of structural paths:

(i) Prior academic achievement at Time $1\left(\mathrm{~T}_{1}\right)$ impacting on effort at Time $2\left(\mathrm{~T}_{2}\right)$, mastery and performance-approach goals at Time $3\left(\mathrm{~T}_{3}\right)$ to Time $5\left(\mathrm{~T}_{5}\right)$, and academic achievement at Time $6\left(\mathrm{~T}_{6}\right)$.

(ii) Effort at $T_{2}$ impacting on mastery and performance-approach goals at $T_{3}$ to $T_{5}$, and academic achievement at $\mathrm{T}_{6}$.

(iii) The initial states and change in mastery and performance-approach goals at $T_{3}$ to $T_{5}$ impacting on academic achievement at $\mathrm{T}_{6}$.

Our conceptualized model signifies three major premises: the postulation of prior academic achievement as a possible antecedent of effort and mastery and performance-approach goals; effort as a possible antecedent of mastery and performance-approach goals; and the examination of initial states and change in mastery and performance-approach goals. Prior academic achievement, as theorized by Bandura (1986, 1997), serves as a source of information for individuals to cognitively appraise their capabilities. The gauging of one's success and/or failure in a subject matter (e.g., algebraic problems involving addition) enables one to formulate and develop a sense of self-efficacy towards different courses of actions (Britner \& Pajares, 2006; e.g., Lent, Lopez, \& Bieschke, 1991; Pajares, Johnson, \& Usher, 2007; Phan, 2011, 2012). Consequently, we query whether this established theoretical tenet could extend to both effort and achievement goal orientations? Does success in a calculus test, say, influence a student to expend more effort in his/her subsequent learning? Similarly, does a pattern in repeated successes inform and motivate students to orientate towards a mastery or performance-approach goal orientation? We contend that achievements via means of competitions and social comparison (e.g., weekly quiz in calculus) may, for instance, compel students to orientate towards a performance-approach goal orientation.

From a longitudinal perspective, especially in higher education settings, the quest for us to seek more 
information about the initial states and change in achievement goals is prudent. As we alluded previously, there is empirical evidence to indicate that students' cognitive (e.g., achievement goal orientations, study processing strategies) and non-cognitive (e.g., personal self-efficacy) processes change over the course of time (Bong, 2002; Caprara et al., 2008; Phan, 2010a, 2011). Consequently, in the context of learning university mathematic, we pose a number of important questions - for example: Does a student's mastery and/or performance-approach goal orientation change over the course of time, based on the influence of prior academic experience?; Does the change in a mastery goal orientation relate to a change in a performance-approach goal? Does effort expenditure influence the initial state of a mastery or performance-approach goal orientation? These questions are prudent, emphasizing in particular the complexities in cognitive processes in a higher education context. Furthermore, the posing of these questions accentuates the paucity of evidence of existing achievement goals models and their explanations of students' learning and behaviors.

In totality, the present study signifies an important paradigm shift in the way we view effort and achievement goal orientations in classroom learning. Differing from previous research studies, our conceptualization illustrates a developmental approach that emphasizes an ongoing system of change. From a methodological point of view, this examination may provide relevant information that could serve to strengthen the conjunctive use of longitudinal data with LGM procedures (Bollen \& Curran, 2006; Duncan et al., 1999; Hancock \& Lawrence, 2006). We contend that findings from our research investigation could serve to contribute and clarify the formation of mastery and performance-approach goals, as well as the trajectories that students may take during their university studies.

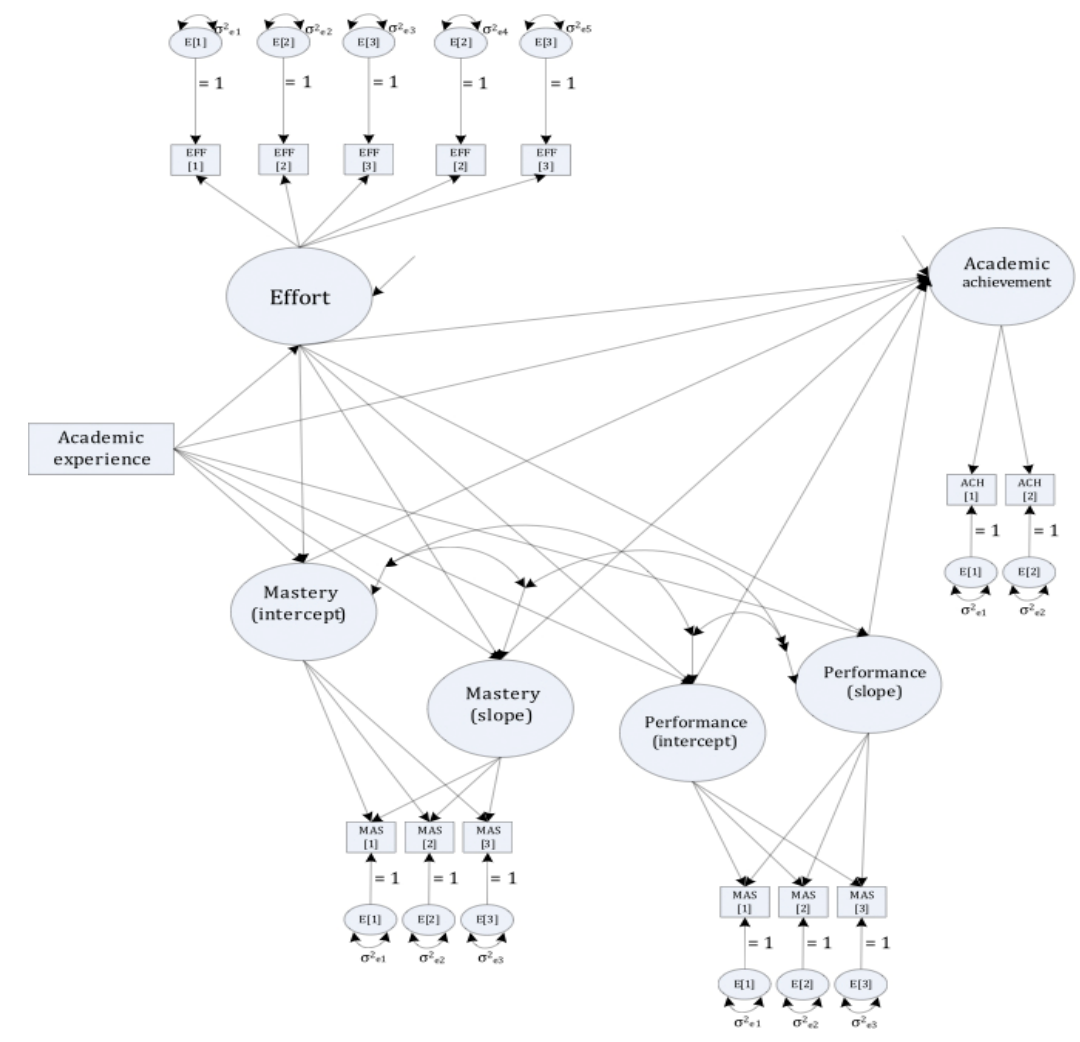

Figure 1. Multivariate growth curve model of prior academic experience, effort, mastery goals and performance-approach goals, and academic achievement

\section{Method}

Participants in this study were 234 first-year university students ( 97 females, 137 males) from a local university in the Asia-Pacific region. The ethnic compositions of the students included, for example, Indo-Fijians, Fijians, and other ethnic groups from small Pacific Island States. The medium of instruction of the university is English and, consequently, the inventories used in this investigation were administered in English. The administration of the questionnaires and the collection of data were as follows: $T_{1}$ - prior academic results for mathematics were 
collected in mid-December, when participants were in first-year; $T_{2}$ - effort measured in the second week of the second year, late-January; mastery and performance-approach goals measured at the end of April for $\mathrm{T}_{3}$, at the end of July for $\mathrm{T}_{4}$, and the beginning of November for $\mathrm{T}_{5}$; and end-of-year results for second-year mathematics in early December for $T_{6}$. We reasoned that the time span specified in this case would provide opportunities for participants to reflect and to adopt appropriate achievement goals in their learning. Methodologically and theoretically, the period between effort at $T_{2}$ and the initial states of mastery and performance-approach goals at $\mathrm{T}_{3}$ is significant in verifying the possible temporally displaced effect of effort. Likewise, the specification of prior academic achievement at $T_{1}$ and final academic achievement at $T_{6}$ is deliberately set in order to ascertain and validate possible temporally displaced effects of prior academic achievement and mastery and performance-approach goals.

\subsection{Instruments}

The items administered were primarily drawn from existing self-report inventories that have been used successfully in previous research studies. Two major inventories were used: achievement goal orientations (Midgley et al., 1998), and effort expenditure (Chouinard et al., 2007; Elliot et al., 1999).

Achievement goals. The items for mastery (6 items) and performance-approach (6 items) reported in the Midgley, et al. (1998) article. Sample items included, for example: "An important reason I do my work in mathematic is because I enjoy it" (mastery scale); and "Doing better than other students in this mathematic is important to me" (performance-approach scale). Participants completed the two scales by indicating their agreement with each of the 10 items on a seven-point scale ranging from 1 ("strongly disagree") to 7 ("strongly agree"). We modified a few wordings to suit the context of university studies in mathematic. Cronbach's alpha values for the mastery goal subscale for the three occasions were $.86\left(\mathrm{~T}_{3}\right), .84\left(\mathrm{~T}_{4}\right)$, and $.95\left(\mathrm{~T}_{5}\right)$; Cronbach's alpha values for the performance-approach goal subscale were $.86\left(\mathrm{~T}_{3}\right), .89\left(\mathrm{~T}_{4}\right)$, and $.90\left(\mathrm{~T}_{5}\right)$. The test-retest reliability coefficients for the performance-approach subscale were $.34\left(\mathrm{~T}_{3}-\mathrm{T}_{4}\right)$ and $.15\left(\mathrm{~T}_{4}-\mathrm{T}_{5}\right)$, and for the mastery subscale, $.74\left(\mathrm{~T}_{3}-\mathrm{T}_{4}\right)$ and $.56\left(\mathrm{~T}_{4}-\mathrm{T}_{5}\right)$.

Effort. Effort was assessed using five items taken from Chouinard, et al.'s (2007) and Elliot et al.'s (1999) studies. Similar to the achievement goals subscales, we made a few minor changes to the wordings so that the five items. Participants completed the scale by indicating their agreement on a seven-point Likert scale ranging from 1 ("strongly disagree") to 7 ("strongly agree"). The items include, for example, "I worked very hard to prepare for mathematic exams", "I put a lot of effort into preparing for mathematic exams", and "I work hard in mathematic". Cronbach's alpha value for this scale administered at $\mathrm{T}_{2}$ was .86 .

Mathematic achievement. Academic achievement in mathematic was measured using two indexes for the unit, Mat200, studied in semester 2 of the second year: participant's continuing course work marks for mathematic $(50 \%)$ and their final mathematic exam results. Similar to mathematic achievement, prior academic in mathematic was measured using course work (50\%) and final exam (50\%) components of the unit Mat100, studied in semester 2 of the first year.

\subsection{Procedure}

Instruments were administered in tutorial classes with the assistance of a research assistant. Participation by the students was voluntary and no remuneration was provided. Students were instructed to write down their names for the purpose of collecting their overall performance marks in mathematic. Students were assured of anonymity, and it was explained why their overall performance marks were needed. Attempts were also made to ensure that any participant missing from a session at a particular time point could complete the questionnaires at an alternative time.

\section{Results}

Our multivariate growth curve model was tested with LISREL 8.8. LGM is advantageous as it enables the study and testing of possible growth in repeated measures over time. Theoretically, as a point of examination, Figure 1 shows a structural representation of intercept and slope factors of mastery and performance-approach goals. The latent observed variables, in this case denoted by MAS $[\mathrm{t}]$ and PER $[\mathrm{t}]$, are the product of latent intercept $\left(\mathrm{y}_{0}\right)$ with unit weights $(=1)$, latent slopes $\left(\mathrm{y}_{1}\right)$ with weights $\mathrm{A}(\mathrm{t}=\alpha[0], \alpha[1], \alpha[2])$, and individual error terms $(\mathrm{e}[\mathrm{t}])$. The initial level and slope are assumed to be random variables with fixed means $\left(\mu_{0}, \mu_{1}\right)$ but random variances $\left(\sigma_{0}^{2}\right.$, $\left.\sigma^{2}{ }_{1}\right)$ and covariances $\left(\sigma_{0,1}^{2}\right)($ McArdle \& Nesselroade, 2003).

To determine the shape of trajectories for the entire sample, we tested two alternative models: a no-growth model, $\mathrm{M}_{0}$, where no slope component was assumed; and a linear-growth model, $\mathrm{M}_{1}$, where we assumed a linear pattern of change over time and fixed values of slope parameters as $\mathrm{A}\left[\mathrm{t}_{1}\right]=0, \mathrm{~A}\left[\mathrm{t}_{2}\right]=1$, and $\mathrm{A}\left[\mathrm{t}_{3}\right]=2$. We also used the 
$\chi^{2}$ difference test for model comparison between the two models. As for the regression factor loadings, we specified structural paths from prior academic achievement and effort to the intercept and slope factors of mastery and performance-approach goals. Likewise, for the relations between the intercept and slope factors of achievement goals, we regressed the following paths: (i) the intercept factor of mastery goals associating with the intercept factor of performance-approach goals, (ii) the slope factor of mastery goals associating with the slope factor of performance-approach goals, and (iii) the intercept and slope factors of mastery and performance-approach goals on academic achievement in mathematics.

A number of goodness-of-fit index values are provided by LISREL include, for example, the Chi-square statistic, the Steiger-Lind root mean square error of approximation (Steiger, 1990) with its $90 \%$ confidence interval, the Bentler comparative fit index (Bentler, 1990), and the Non-normed fit index (Bentler \& Bonett, 1980). Conventionally, models with CFI and NNFI values over .90 and RMSEA values below .06 are normally considered as being acceptable in fit (Byrne, 1998; Kline, 2011; Schumacker \& Lomax, 2004).

Multivariate growth curve analysis. Means and standard deviations for prior academic achievement at $\mathrm{T}_{1}$, effort at $T_{2}$, mastery and performance-approach goals at $T_{3}$ to $T_{5}$, and mathematic results at $T_{6}$ are presented in Table 1 . In our preliminary analyses, we noted that the kurtosis values for the measured indicators ranged from -.14 to .98 , and the skewness values ranged from -.45 to .82; these values indicate a normal distribution of the data (Kline, 2011). Our initial analysis of the no-growth model (Model $\left.\mathrm{M}_{0}\right)$ showed an average model fit $\left(\chi_{(66)}^{2}=173.01\right.$, CFI $=.86, \mathrm{NNFI}=.85, \mathrm{RMSEA}=.10$ ). For the linear-growth model, we performed two models: Model $\mathrm{M}_{1 \mathrm{~A}}$, where the intercept factors between mastery and performance-approach goals, and the slope factors between mastery and performance-approach goals were not specified; the goodness-of-fit index values showed an adequate model fit $\left(\chi_{(63)}^{2}=149.18, \mathrm{CFI}=.92, \mathrm{NNFI}=.89, \mathrm{RMSEA}=.08\right)$. Model $\mathrm{M}_{1 \mathrm{~B}}$ is identical to Model $\mathrm{M}_{1 \mathrm{~A}}$ with the exception of specified associations for the intercept and slope factors between mastery and performance-approach goals; this model showed an excellent fit $\left(\chi_{(61)}^{2}=123.35\right.$, CFI $=.94$, NNFI $=.91$, RMSEA $=.07$ ). The $\chi^{2}$ difference tests (Bollen, 1989; Byrne, 1998) showed the acceptance of Model $\mathrm{M}_{1 \mathrm{~A}}\left(\Delta \chi_{(\mathrm{M} 1 \mathrm{~A}-\mathrm{M} 0)}^{2}(3, N=232)=23.83, p<.001\right)$ and, consequently, Model $\mathrm{M}_{1 \mathrm{~B}}\left(\Delta \chi_{(\mathrm{M} 1 \mathrm{~B}-\mathrm{M} 1 \mathrm{~A})}^{2}(2, N=232)=25.83\right.$, $p<.001$ ), our a proposed a priori model.

Examination of parameter estimates from Table 2 and direct and indirect effects from Table 3 indicated four statistically significant structural paths: the effects of effort on the intercept factor of mastery goals $(\mathrm{B}=.32, S E$ $=.09, p<.001)$ and academic achievement in mathematics $(\mathrm{B}=.31, S E=.07, p<.001)$; and the effects of prior academic achievement on the intercept factor of performance-approach goals $(\mathrm{B}=.16, S E=.09, p<.05)$ and academic achievement in mathematics $(\mathrm{B}=.11, S E=.04, p<.01)$. For a mastery goal orientation, the variance of intercept $\left(\sigma^{2}=1.23, S E=.47, p<.01\right)$ was significant whereas the variance of slope $\left(\sigma^{2}=.23, S E=.23, n s\right)$ was not, thus suggesting that there was meaningful individual variability around the group average but not in the change over time. The intercept mean was significantly different from zero $(M=5.33, p<.001)$ and the slope mean was negative and significantly different from zero $(M=-.02, p<.001)$, indicating that students' mastery goal orientation decreased over time.

Table 1. Means and standard deviations for constructs across Time 1 - Time 3

\begin{tabular}{llll}
\hline Constructs & Total & Men & Women \\
\hline Prior academic achievement $-\mathrm{T}_{1}$ & $51.69(15.16)$ & $52.47(16.09)$ & $50.60(13.73)$ \\
Effort $-\mathrm{T}_{2}$ & $5.14(1.61)$ & $5.18(1.65)$ & $5.08(1.58)$ \\
Mathematics Course mark $-\mathrm{T}_{6}$ & $64.91(11.91)$ & $64.53(13.01)$ & $65.46(10.21)$ \\
Mathematics test $-\mathrm{T}_{6}$ & $60.34(11.45)$ & $59.93(12.10)$ & $60.93(10.52)$ \\
Mastery $-\mathrm{T}_{3}$ & $5.70(1.60)$ & $5.79(1.58)$ & $5.57(1.63)$ \\
Mastery $-\mathrm{T}_{4}$ & $5.20(2.27)$ & $5.19(2.25)$ & $5.22(2.32)$ \\
Mastery $-\mathrm{T}_{5}$ & $5.36(2.02)$ & $5.54(1.98)$ & $5.10(2.06)$ \\
Performance-approach $-\mathrm{T}_{3}$ & $5.37(2.24)$ & $5.22(2.38)$ & $5.59(2.00)$ \\
Performance-approach $-\mathrm{T}_{4}$ & $4.61(2.23)$ & $4.39(2.27)$ & $4.92(2.13)$ \\
Performance-approach $-\mathrm{T}_{5}$ & $5.37(1.98)$ & $5.34(2.00)$ & $5.41(1.96)$ \\
\hline
\end{tabular}

Note. Standard deviation scores are shown in brackets. 
Table 2. Parameter estimates, standard errors, and critical ratios for multivariate growth curve model

\begin{tabular}{|c|c|c|c|c|}
\hline & Estimate & & Std. error & Critical ratio \\
\hline \multicolumn{5}{|l|}{ Factor loadings } \\
\hline Time $1 \rightarrow$ Mastery slope & $0=$ & & & \\
\hline Time $2 \rightarrow$ Mastery slope & $=$ & & & \\
\hline Time $3 \rightarrow$ Mastery slope & $1=$ & & & \\
\hline Time $1 \rightarrow$ Performance-approach slope & $0=$ & & & \\
\hline Time $2 \rightarrow$ Performance-approach slope & $=$ & & & \\
\hline Time $3 \rightarrow$ Performance-approach slope & $1=$ & & & \\
\hline \multicolumn{5}{|l|}{ Regression effects on intercept } \\
\hline Academic experience $\rightarrow$ Mastery intercept & .08 & & .07 & 1.13 \\
\hline Effort $\rightarrow$ Mastery intercept & .32 & $* * *$ & .09 & 3.52 \\
\hline $\begin{array}{l}\text { Academic experience } \rightarrow \text { Performance-approach } \\
\text { intercept }\end{array}$ & .16 & * & .09 & 1.77 \\
\hline Effort $\rightarrow$ Performance-approach intercept & .03 & & .12 & .24 \\
\hline \multicolumn{5}{|l|}{ Regression effects on slope } \\
\hline Academic experience $\rightarrow$ Mastery slope & .04 & & .05 & .74 \\
\hline Effort $\rightarrow$ Mastery slope & -.02 & & .06 & -.37 \\
\hline $\begin{array}{l}\text { Academic experience } \rightarrow \text { Performance-approach } \\
\text { slope }\end{array}$ & .01 & & .05 & .20 \\
\hline Effort $\rightarrow$ Performance-approach slope & .05 & & .07 & .74 \\
\hline \multicolumn{5}{|l|}{ Regression effects on effort } \\
\hline Prior academic experience & -.02 & & .05 & -.31 \\
\hline \multicolumn{5}{|l|}{ Regression effects on academic achievement } \\
\hline Prior academic experience & .11 & $* *$ & .04 & 2.79 \\
\hline Effort & .31 & $* * *$ & .07 & 4.52 \\
\hline Mastery intercept & -.02 & & .10 & -.17 \\
\hline Mastery slope & -.13 & & .40 & -.32 \\
\hline Performance-approach intercept & -.02 & & .07 & -.23 \\
\hline Performance-approach slope & .02 & & .19 & .10 \\
\hline \multicolumn{5}{|l|}{ Factor means } \\
\hline Prior academic experience & 5.17 & $* * *$ & .10 & 2.17 \\
\hline \multicolumn{5}{|l|}{ Factor variances } \\
\hline Mastery intercept & 1.23 & $* *$ & .47 & 2.63 \\
\hline Mastery slope & .23 & & .23 & .99 \\
\hline Performance-approach intercept & 1.77 & $* *$ & .55 & 3.25 \\
\hline Performance-approach slope & .46 & & .25 & 1.81 \\
\hline \multicolumn{5}{|l|}{ Factor covariances } \\
\hline Mastery intercept $\leftrightarrow$ Mastery slope & -.25 & & .27 & -.92 \\
\hline $\begin{array}{ll}\text { Performance-approach } & \text { intercept } \\
\text { Performance-approach slope } & \end{array}$ & -.19 & & .29 & -.66 \\
\hline $\begin{array}{l}\text { Mastery intercept } \leftrightarrow \text { Performance-approach } \\
\text { intercept }\end{array}$ & .49 & $* *$ & .15 & 3.26 \\
\hline Mastery slope $\leftrightarrow$ Performance-approach slope & .14 & $*$ & .06 & 2.27 \\
\hline
\end{tabular}

Note. $* p<.05, * * p<.01, * * * p<.001$. 
Table 3. Direct, indirect, and total effects

\begin{tabular}{|c|c|c|c|c|c|c|}
\hline Predictor & Outcome & \multicolumn{2}{|c|}{ Direct effect } & Indirect effect & \multicolumn{2}{|c|}{ Total effect } \\
\hline Prior academic achievement & Effort & -.02 & & .00 & -.02 & \\
\hline Effort & Mastery intercept & .33 & $* * *$ & .00 & .33 & $* * *$ \\
\hline Prior academic achievement & & .09 & & -.01 & .09 & \\
\hline Mastery intercept & Mastery slope & .00 & & .00 & .00 & \\
\hline Effort & & -.06 & & .00 & -.06 & \\
\hline Prior academic achievement & & .11 & & .00 & .11 & \\
\hline Mastery slope & $\begin{array}{l}\text { Performance-approach } \\
\text { intercept }\end{array}$ & .00 & & .00 & .00 & \\
\hline Mastery intercept & & .00 & & .00 & .00 & \\
\hline Effort & & .03 & & .00 & .03 & \\
\hline Prior academic achievement & & .18 & $*$ & .00 & .18 & $*$ \\
\hline Performance-approach intercept & $\begin{array}{l}\text { Performance-approach } \\
\text { slope }\end{array}$ & .00 & & .00 & .00 & \\
\hline Mastery slope & & .00 & & .00 & .00 & \\
\hline Mastery intercept & & .00 & & .00 & .00 & \\
\hline Effort & & .09 & & .00 & .09 & \\
\hline Prior academic achievement & & .02 & & .00 & .02 & \\
\hline Performance-approach slope & Academic achievement & .02 & & .00 & .02 & \\
\hline Performance-approach intercept & & -.03 & & .00 & -.03 & \\
\hline Mastery slope & & -.07 & & .00 & -.07 & \\
\hline Mastery intercept & & -.02 & & .00 & -.02 & \\
\hline Effort & & .45 & $* * *$ & .00 & .45 & $* * *$ \\
\hline Prior academic achievement & & .20 & $* * *$ & -.02 & .18 & $* * *$ \\
\hline
\end{tabular}

\section{Discussion}

This research investigation, differing from previous studies, characteristically emphasized the initial states and growth of mastery and performance-approach goals in learning. Specifically, our hypothesized structural paths acknowledged the possible formation of these two goal types via prior academic achievement and effort expenditure. In general, the evidence obtained provides moderate, but yet important contribution for the study of achievement goals.

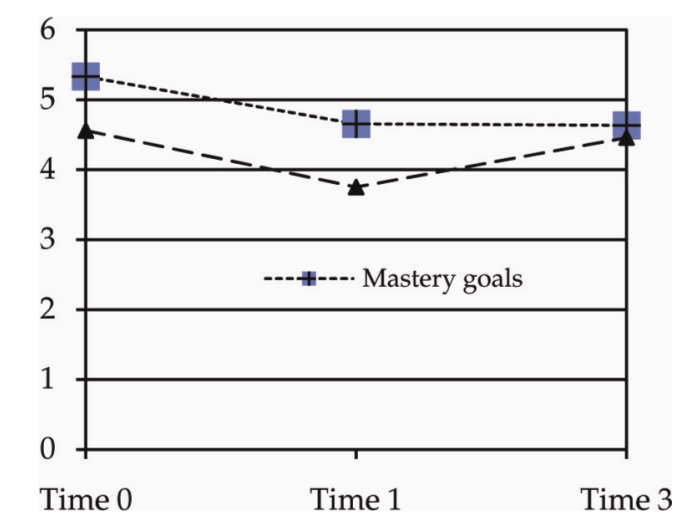

Figure 2. Growth curve change of mastery and performance-approach goals over Time 3 to Time 5 


\subsection{Formation of Achievement Goals}

Drawing from social cognitive theory (Bandura, 1986, 1997), we posed one major question: how do students form their and develop their goal orientations towards learning? Existing research studies in cognition and motivation have reported evidence attesting to the contributions of self-efficacy (Fenollar et al., 2007; Liem et al., 2008; Phan, 2010b) and prior academic achievement (Phan, 2010a) on mastery and performance-approach goals. Our findings, similarly, indicate that both effort and prior academic achievement influence mastery and performance-approach goal orientations, respectively. Expending effort in learning (e.g., "I need to spend more time and study harder") is pivotal for students who wish to pursue and align to individual growth and mastery of skills. This analogous association is important and raises questions for continuing research - for example: Do effort and mastery goals parallel each other over time? Does the increase or decrease in effort also influence the change in mastery goals? Are there external correlates that may account and explain the interrelations between effort and mastery goals?

A performance-approach goal orientation in this study, in contrast, was influenced by prior academic achievement in mathematic. Previous learning experiences, based on performances and competitions (e.g., "I'm doing very well this semester; I've been coming first and second in this unit"), permeate a preference towards objectives and goals that accentuate the importance of distinctions and normative evaluation. In this analysis, a student's prior academic success, graded normatively, is more than likely to strengthen his/her personal resolve and egoistically feeling for further needs to achieve (e.g., "I need to do well in this test"). In contrast, prior failure in mathematic weakens a student's resolve and motive for learning, especially if normative evaluation and social comparison are made.

The findings and discussion offered in this section provide a premise for consideration into applied teaching practice and continuing research development. Given the significance in relations between effort and mastery goal orientations, and between prior academic achievement and performance-approach goal orientations, it is prudent for educators to deliberate and structure pedagogical strategies that could strengthen these emphases. Reflecting on personal success or failure in achievements and accomplishments may help in the articulation of motives for learning, as well as strengthen one's resolve to persist even in the face of obstacles. What is needed, perhaps, is a structuring of assessment tasks that are based predominantly on mastery criteria, rather than social comparison per se. We feel that accomplishments via means of personal criteria (e.g., "Can I complete this task?") are more effective in facilitating students to develop a thinking that reflects personal growth and improvement in competence. In a similar vein, the use of appropriate self-regulatory strategies (e.g., time management)(Schunk \& Zimmerman, 1998; Zimmerman, 2002; Zimmerman \& Risemberg, 1997; Zimmerman $\&$ Schunk, 2001) may also facilitate students' effort expenditure towards effective learning outcomes. In contrast, however, a belief in meaningful and mastery learning may weaken, given its lesser emphasis and priority.

\subsection{Trajectories of Mastery and Performance-approach Goals}

Our multivariate growth curve analyses indicated contrasting changes for both mastery and performance-approach goals: a small decline in mastery goals and an increase in performance-approach goals over the three occasions. This disparity between the two goal types is significant, and reflects, in our view, the reality of university learning. The need to compete and excel academically for future career prospects may compel students' thinking, personal beliefs, and motives towards achievement and performance-based criteria for example, "I need to do well in my studies in order to get a good job later on". In a similar vein, the thinking that good job prospects depend, in part, on competitions may also consequently give rise to alignment in social comparison and normative evaluation.

Statistically significant correlations between the slope factors of mastery and performance-approach goals $(r$ $=.33)$, and between the intercept factors of mastery and performance-approach goals $(r=.42)$ were also observed. This finding emphasizes, in particular, the intricate associations between the different types of achievement goals. It is interesting to note from the onset of learning that students reported higher scores for mastery goals than performance-approach goals but, over the course of time, there was a decline in the former and an increase in the latter.

Theoretically, our findings have contributed to the understanding that achievement goals, in general, are not static, but rather amend to change based on learning contexts and other extraneous factors. Having said this, we also note that prior achievement and effort did not influence changes in mastery and performance-approach goal orientations. The $R^{2}$ values for the slope factors of mastery and performance-approach goals were relatively small (i.e., $1.5 \%$ and $.80 \%$, respectively), suggesting a number of unknowns that could also account for these variances. Previous literature has suggested, for example, that the classroom environment could play a major role 
in making certain goals salient for classroom learning (e.g., Ames, 1992; Anderman \& Midgley, 1997; Lau \& Nie, 2008; Urdan, Kneisel, \& Mason, 1999). Instructional policies and practices, accentuating specific assessment tasks (e.g., periodic quizzes for a unit) may, for instance, encourage and enhance a performance-approach goal structure (Urdan, 2004). Similarly the use of self-reflection assessments (e.g., collective portfolios) may, in contrast, cultivate a mastery goal approach. Future research could, consequentially, advance our focus by exploring the possible effects of other external factors.

\subsection{Prior Academic Achievement, Effort, and Achievement Goals and Academic Learning}

Our multivariate growth curve analyses also yielded two major findings: the effect of prior academic achievement and effort on mathematic achievement. In contrast, however, we noted a lack in associations between the initial states and change in mastery and performance-approach goals and mathematic achievement. Previous research studies have, though, reported non-statistical significance for both mastery goal (Senko \& Miles, 2008; Sins, van Joolingen, Savelsbergh, \& van Hout-Wolters, 2008) and performance-approach goal (Dupeyrat \& Mariné, 2005; Fenollar et al., 2007; Liem et al., 2008) orientations. We offer two possible explanations for this absence in associations. First, both mastery and performance-approach goals could have influenced mathematic achievement, indirectly, via other cognitive processes such as effort (Elliot et al., 1999; Fenollar et al., 2007), persistence (Elliot et al., 1999), and study processing strategies (Fenollar et al., 2007; Phan, 2010b; Simons et al., 2004). Second, the constructive misalignment in learning objectives, teaching and, consequently, assessment outcomes (Biggs, 1999; Biggs \& Tang, 2007) may also account and explain non-statistical significant relations between achievement goals and achievement learning outcomes. This emphasis on constructive alignment has researched in other areas, such as student approaches to learning and reflective thinking (Phan, 2008). A student who wishes to pursue individual growth and personal accomplishments, reflecting mastery and deep learning, may come to the realization that periodic academic results for quizzes, say, do not necessarily coincide with his/her learning objectives, desires, and/or ambitions.

\section{Conclusion}

The research study reported in this article has contributed, theoretically and methodologically, to the study of students' learning. Differing from previous research, we amalgamated two major theoretical orientations and independent strands of inquiries, achievement goal orientations and effort, in our conceptual model for examination. Evidence ascertained from our growth curve analyses yielded three major emphases: (i) identification of effort and prior academic achievement as antecedents of initial states of mastery and performance-approach goals, respectively; (ii) the tracing of developmental trajectories of mastery and performance-approach goals over time; and (iii) the associations between the initial states of mastery and performance-approach goals, and between the changes in both achievement goals over time.

Overall, based on our findings, there is credence to contend that continuing advancement into the conceptualization and research development of achievement goal orientations is therefore needed. Evidence ascertained from our research investigation illustrates, in particular, the complexities of students' learning in higher education contexts. Longitudinal examination has captured the intricacy of internal cognitive processes, notably effort expenditure and achievement goal orientations, over the course of undergraduate studies. Educators and researchers could, drawing from this emphasis, extend the research foci made in this study, and explore students' trajectories using other methodological approaches.

Despite the empirical and theoretical contributions that we have made, there are a number of caveats that require continuing examination and research development. Firstly, from a methodological perspective, we need to consider the embracing and use of alternative, non-quantitative techniques in our examination of students' achievement goal orientations (e.g., mastery versus performance-approach). Statistical testing of data, using complex causal modeling procedures, say, may limit us from making theoretical inference about the underlying process of how effort expenditure account and explain for the preference of mastery and/or performance-approach goals. Qualitative examination, involving the use of in situ observations or open-ended surveys may elicit more in-depth information pertaining to the intricacy of internal cognitive processes of effective learning (e.g., effort expenditure). The recent work of Phan (2012-In press), for example, has yielded some important qualitative evidence, attesting to the various facets and facets that explain different achievement goal orientations.

Secondly, similar to our first point of noting for research development, advanced emphasis may also entail a comparative analysis of students' cognitive processes and learning in different socio-cultural settings. This avenue of inquiry has emerged recently, with reported evidence (Lau \& Nie, 2008; Phan \& Deo, 2008; Walker, Pressick-Kilborn, Arnold, \& Sainsbury, 2004) that emphasize the contextualized nature of motivational beliefs 
and learning. We contend that sophisticated statistical procedures, such as hierarchical linear modeling (HLM) (Little, 2000; MacCallum, Kim, Malarkey, \& Kiecolt-Glaser, 1997; Raudenbush \& Bryk, 2001; Skrondal \& Rabe-Hesketh, 2004) may shed complimentary and/or extended findings into relationships between achievement goals and students' academic learning. University learning and the social context at large are complex and require, in particular, multi-level analyses that could discern disparate levels of educational and social influences. One possible research focus that could be made, for instance, entails the tracing of impact of the university schooling system, and how students situate within the hierarchical structures that include the family, tutorial classroom, university and country. As an example, students within a particular tutorial class or workshop may share similar cultural values, family background, socioeconomical status and/or educational preparation. These students may also share a collective sense of experience of being in a classroom milieu that differs from another classroom environment. This complexity and hierarchical structuring may, in turn, impact on the growth and trajectories of group level variables (e.g., classroom milieu) and individualized cognitive-motivational processes (e.g., effort expenditure).

Thirdly, apart from examination of initial states and rates of growth, researchers could also explore the reciprocal causal relations between effort expenditure, achievement goals, and academic achievement. Our data collection and hypotheses were limited, enabling a unidirectional approach in statistical testing between the variables (e.g., effort expenditure $\rightarrow$ a mastery goal orientation). We concur that the notion of reciprocality, similar to the study of self-concept (Helmke \& van Aken, 1995; Marsh \& Craven, 2006; Marsh \& Yeung, 1997; Skaalvik \& Rankin, 1998), may extend to the dynamic interrelations between effort expenditure and achievement goals. Data collected at multiple time points and analyzed within the framework of SEM may provide empirical insight into the cognitive processes of learning - for example, a student adopting a mastery goal orientation may, consequently, develop deep meaningful self-regulated strategies for effective learning (e.g., managing appropriate time and effort expenditure). We also note that the inclusion of constructs in our examination and analyses was simplistic, and that other achievement-related constructs could be tested. Researchers could, for example, consider the $2 \times 2$ achievement goals theoretical model (Elliot, 1999; Elliot \& McGregor, 2001) within the framework of sociocultural influences (e.g., the impact of the home environment) and non-cognitive processes (e.g., personal self-efficacy).

\section{References}

Ames, C. (1992). Classrooms: Goals, structures, and student motivation. Journal of Educational Psychology, 84, 261-271. http://dx.doi.org/10.1037/0022-0663.84.3.261

Ames, C., \& Archer, J. (1988). Achievement goals in the classroom: Students' learning strategies and motivation processes. Journal of Educational Psychology, 80, 260-267. http://dx.doi.org/10.1037/0022-0663.80.3.260

Anderman, E., \& Midgley, C. (1997). Changes in personal achievement goals and the perceived classroom goal structures across the transition to middle level schools. Contemporary Educational Psychology, 22, 269-298. http://dx.doi.org/10.1006/ceps.1996.0926

Bandura, A. (1986). Social foundations of thought and action: A social cognitive theory. New Jersey: Prentice-Hall, Inc.

Bandura, A. (1997). Self-efficacy: The exercise of control. New York: W. H. Freeman \& Co.

Bentler, P. M. (1990). Comparative fit indexes in structural models. Psychological Bulletin, 107, 238-246. http://dx.doi.org/10.1037/0033-2909.107.2.238

Bentler, P. M., \& Bonett, D. G. (1980). Significance tests and goodness of fit in the analysis of covariance structures. Psychological Bulletin, 88, 588-606. http://dx.doi.org/10.1037/0033-2909.88.3.588

Biggs, J. (1999). Teaching for quality learning at university. Buckingham: Open University Press.

Biggs, J., \& Tang, C. (2007). Teaching for quality learning at university. Maidenhead: McGraw-Hill/Society for Research into Higher Education \& Open University Press.

Bollen, K. A. (1989). Structural equations with latent variables. New York: Wiley.

Bollen, K. A., \& Curran, P. J. (2006). Latent curve models: A structural equation perspective. Hoboken, NJ: Wiley.

Bong, M. (2002). Stability and structure of self-efficacy, task-value, and achievement goals and consistency of their relations across specific and general academic contexts and across the school year. Paper presented at the American Educational Research Association (AERA). New Orleans, LA, 2002, New Orleans, LA. 
Britner, S. L., \& Pajares, F. (2006). Sources of science self-efficacy beliefs of middle school students. Journal of Research in Science Teaching, 43, 485-499. http://dx.doi.org/10.1002/tea.20131

Byrne, B. M. (1998). Structural equation modelling with LISREL, PRELIS, and SIMPLIS. Mahwah, NJ: Erlbaum.

Caprara, G. V., Fida, R., Vecchione, M., Del Bove, G., Vecchio, G. M., Barbaranelli, C., \& Bandura, A. (2008). Longitudinal analysis of the role of perceived self-efficacy for self-regulated learning in academic continuance and achievement. Journal of Educational Psychology, 100(3), 525-534. http://dx.doi.org/10.1037/0022-0663.100.3.525

Chouinard, R., Karsenti, T., \& Roy, N. (2007). Relations among competence beliefs, utility value, achievement goals, and effort in mathematics. British Journal of Educational Psychology, 77, 501-517. http://dx.doi.org/10.1348/000709906X133589

Church, M. A., Elliot, A. J., \& Gable, S. L. (2001). Perceptions of classroom environment, achievement goals, and achievement outcomes. Journal of Educational Psychology, 93, 43-54. http://dx.doi.org/10.1037/0022-0663.93.1.43

Cole, J. S., Bergin, D. A., \& Whittaker, T. A. (2008). Predicting student achievement for low stakes tests with effort and task value. Contemporary Educational Psychology, 33, 609-624. http://dx.doi.org/10.1016/j.cedpsych.2007.10.002

Covington, M. V. (2000). Goal theory, motivation, and school achievement: An integrative review. Annual Review of Psychology, 51, 171-200. http://dx.doi.org/10.1146/annurev.psych.51.1.171

Deshon, R. P., \& Gillespie, J. Z. (2005). A motivated action theory account of goal orientation. Journal of Applied Psychology, 90, 1096-1127. http://dx.doi.org/10.1037/0021-9010.90.6.1096

Duncan, T. E., Duncan, S. C., Strycker, L. A., Li, F., \& Alpert, A. (1999). An introduction to latent variable growth curve modelling: Concepts, issues, and applications. Mahwah, NJ: Erlbaum.

Dupeyrat, C., \& Mariné, C. (2005). Implicit theories of intelligence, goal orientation, cognitive engagement, and achievement: A test of Dweck's model with returning to school adults. Contemporary Educational Psychology, 30, 43-59. http://dx.doi.org/10.1016/j.cedpsych.2004.01.007

Durik, A. M., Lovejoy, C. M., \& Johnson, S. J. (2009). A longitudinal study of achievement goals for college in general: Predicting cumulative GPA and diversity in course selection. Contemporary Educational Psychology, 34, 113-119. http://dx.doi.org/10.1016/j.cedpsych.2008.11.002

Dweck, C. S., \& Leggett, E. L. (1988). A social-cognitive approach to motivation and personality. Psychological Review, 95, 256 - 273. http://dx.doi.org/10.1037/0033-295X.95.2.256

Elliot, A. J. (1999). Approach and avoidance motivation and achievement goals. Educational Psychologist, 34, 169-189. http://dx.doi.org/10.1207/s15326985ep3403_3

Elliot, A. J., \& Church, M. A. (1997). A hierarchical model of approach and avoidance achievement motivation. Journal of Personality and Social Psychology, 72, 218-232. http://dx.doi.org/10.1037/0022-3514.72.1.218

Elliot, A. J., \& Harackiewicz, J. M. (1996). Approach and avoidance achievement goals and intrinsic motivation: A mediational analysis. Journal of Personality and Social Psychology, 70, 461-475. http://dx.doi.org/10.1037/0022-3514.70.3.461

Elliot, A. J., \& McGregor, H. A. (2001). A 2 x 2 achievement goal framework. Journal of Personality and Social Psychology, 80, 501-519. http://dx.doi.org/10.1037/0022-3514.80.3.501

Elliot, A. J., McGregor, H. A., \& Gable, S. (1999). Achievement goals, study strategies, and exam performances: A mediational analysis. Journal of Educational Psychology, 91, 549-563. http://dx.doi.org/10.1037/0022-0663.91.3.549

Elliot, A. J., \& Murayama, K. (2008). On the measurement of achievement goals: Critique, illustration, and $\begin{array}{lllll}\text { application. Journal of Educational Psychology, } & \text { 100(3), }\end{array}$ http://dx.doi.org/10.1037/0022-0663.100.3.613

Elliot, A. J., Shell, M. M., Henry, K. B., \& Maier, M. A. (2005). Achievement goals, performance contingencies, and performance atttainment: An experimental test. Journal of Educational Psychology, 97(4), 630-640. http://dx.doi.org/10.1037/0022-0663.97.4.630

Elliott, E. S., \& Dweck, C. S. (1988). Goals: An approach to motivation and achievement. Journal of Personality 
and Social Psychology, 54, 5-12. http://dx.doi.org/10.1037/0022-3514.54.1.5

Fenollar, P., Román, S., \& Cuestas, P. J. (2007). University students' academic performance: An integrative conceptual framework and empirical analysis. British Journal of Educational Psychology, 77, 873-891. http://dx.doi.org/10.1348/000709907X189118

Greene, B. A., Miller, R. B., Crowson, M. D., Duke, B., \& Akey, K. (2004). Predicting high school students' cognitive engagement and achievement: Contributions of classroom perceptions and motivation. Contemporary Educational Psychology, 29, 499-517. http://dx.doi.org/10.1016/j.cedpsych.2004.01.006

Hancock, G. R., \& Lawrence, F. R. (2006). Using latent growth models to evaluate longitudinal change. In G. R. Hancock \& R. O. Mueller (Eds.), Structural equation modeling: A second course (pp. 171-196). Greenwich, Connecticut: Information Age Publishing.

Harackiewicz, J. M., Barron, K. E., Pintrich, P. R., Elliot, A. J., \& Trash, T. M. (2002). Revision of achievement goal theory: Necessary and illuminating. Journal of Educational Psychology, 94, 638-645. http://dx.doi.org/10.1037/0022-0663.94.3.638

Harackiewicz, J. M., Barron, K. E., Tauer, J. M., \& Elliot, A. J. (2002). Predicting success in college: A longitudinal study of achievement goals and ability measures as predictors of interest and performance from freshman year through graduation. Journal of Educational Psychology, 94, 562-575. http://dx.doi.org/10.1037/0022-0663.94.3.562

Helmke, A., \& van Aken, M. A. G. (1995). The causal ordering of academic achievement and self-concept of ability during elementary school: A longitudinal study. Journal of Educational Psychology, 87, 624-637. http://dx.doi.org/10.1037/0022-0663.87.4.624

Kim, J., \& Cicchetti, D. (2006). Longitudinal trajectories of self-system processes and depressive symptoms among maltreated and nonmaltreated children. Child Development, 77, 624-639. http://dx.doi.org/10.1111/j.1467-8624.2006.00894.x

Kline, R. B. (2011). Principles and practice of structural equation modeling (3rd ed.). New York, NY: The Guilford Press.

Lau, S., \& Nie, Y. (2008). Interplay between personal goals and classroom goal structures in predicting student outcomes: A multilevel analysis of person-context interactions. Journal of educational Psychology, 100(1), 15-29. http://dx.doi.org/10.1037/0022-0663.100.1.15

Lent, R. W., Lopez, F. G., \& Bieschke, K. J. (1991). Mathematics self-efficacy: Sources and relation to science-based career choice. Journal of Counseling Psychology, 38, 424-430. http://dx.doi.org/10.1037/0022-0167.38.4.424

Liem, A. D., Lau, S., \& Nie, Y. (2008). The role of self-efficacy, task value, and achievement goals in predicting learning strategies, task disengagement, peer relationship, and achievement outcome. Contemporary Educational Psychology, 33, 486-512. http://dx.doi.org/10.1016/j.cedpsych.2007.08.001

Little, T. D. (2000). Modeling longitudinal and multilevel data: Practical issues, applied approaches, and specific examples. Mahwah, NJ: Lawrence Erlbaum.

MacCallum, R. C., Kim, C., Malarkey, W. B., \& Kiecolt-Glaser, J. K. (1997). Studying multivariate change using multilevel models and latent curve models. Multivariate Behavioral Research, 32(3), 215-253. http://dx.doi.org/10.1207/s15327906mbr3203_1

Marsh, H. W., \& Craven, R. G. (2006). Reciprocal effects of self-concept and performance from a multidimensional perspective: Beyond seductive pleasure and unidimensional perspectives. Perspectives on Psychological Science, 1, 133-163. http://dx.doi.org/10.1111/j.1745-6916.2006.00010.x

Marsh, H. W., \& Yeung, A. S. (1997). Causal effects of academic self-concept on academic achievement: Structural equation models of longitudinal data. Journal of Educational Psychology, 89(1), 41-54. http://dx.doi.org/10.1037/0022-0663.89.1.41

McArdle, J. J., \& Nesselroade, J. R. (2003). Growth curve analysis in contemporary psychological research. In J. A. Schinka \& W. F. Velicer (Eds.), Handbook of psychology: Research methods in psychology (pp. 447-480). New York: Wiley.

Meece, J. L., Blumenfeld, P. C., \& Hoyle, R. H. (1988). Students' goal orientations and cognitive engagement in classroom activities. Journal of Educational Psychology, 80, 514-523. http://dx.doi.org/10.1037/0022-0663.80.4.514 
Midgley, C., Kaplan, A., Middleton, M., Maehr, M. L., Urdan, T., Anderman, L. H., . . Roeser, R. (1998). The development and validation of scales assessing students' achievement goal orientations. Contemporary Educational Psychology, 23, 113-131. http://dx.doi.org/10.1006/ceps.1998.0965

Nicholls, J. (1984). Achievement motivation: Conceptions of ability, subjective experience, task choice, and performance. Psychological Review, 91, 328-346. http://dx.doi.org/10.1037/0033-295X.91.3.328

Nolen, S. B., \& Haladyns, T. M. (1990). Personal and environmental influences on students' beliefs about effective study strategies. Contemporary Educational Psychology, 15, 116-130. http://dx.doi.org/10.1016/0361-476X(90)90011-O

Odgers, C. L., Moffitt, T. E., Tach, L. M., Sampson, R. J., Taylor, A., \& Matthews, C. L. (2009). The protective effects of neighborhood collective efficacy on British children growing up in deprivation: A developmental analysis. Developmental Psychology, 45(4), 942-957. http://dx.doi.org/10.1037/a0016162

Pajares, F., Johnson, J., J, \& Usher, E. L. (2007). Sources of writing self-efficacy beliefs of elementary, middle, and high school students. Research in the Teaching of English, 42(1), 104-120.

Pekrun, R., Elliot, A. J., \& Maier, M. A. (2009). Achievement goals and achievement emotions: Testing a model of their joint relations with academic performance. Journal of educational Psychology, 101(1), 115-135. http://dx.doi.org/10.1037/a0013383

Phan, H. P. (2008). Unifying different theories of learning: Theoretical framework and empirical evidence. Educational Psychology, 28(3), 325-340. http://dx.doi.org/10.1080/01443410701591392

Phan, H. P. (2009a). Amalgamation of future time orientation, epistemological beliefs, achievement goals and study strategies: Empirical evidence established. British Journal of Educational Psychology, 79, 155-173. http://dx.doi.org/10.1348/000709908X306864

Phan, H. P. (2009b). Exploring students' reflective thinking practice, deep processing strategies, effort, and

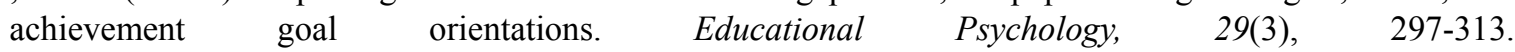
http://dx.doi.org/10.1080/01443410902877988

Phan, H. P. (2009c). Relations between goals, self-efficacy, critical thinking and deep processing strategies: A path analysis. Educational Psychology, 29(7), 777-799. http://dx.doi.org/10.1080/01443410903289423

Phan, H. P. (2010a). Empirical model and analysis of mastery and performance-approach goals: A developmental approach. Educational Psychology, 30(5), 547-564. http://dx.doi.org/10.1080/01443410.2010.491936

Phan, H. P. (2010b). Students' academic performance and various cognitive processes of learning: An integrative framework and empirical analysis. Educational Psychology, 30(3), 297-322. http://dx.doi.org/10.1080/01443410903573297

Phan, H. P. (2011). Interrelations between self-efficacy and learning approaches: A developmental approach. Educational Psychology, 31(2), 225-246. http://dx.doi.org/10.1080/01443410.2010.545050

Phan, H. P. (2012). The development of English and mathematics self-efficacy: A latent growth curve analysis. The Journal of Educational Research, 105, 196-209. http://dx.doi.org/10.1080/00220671.2011.552132

Phan, H. P., \& Deo, B. (2008). "Revisiting" the South Pacific approaches to learning: A confirmatory factor analysis study. Higher Education Research and Development, 27(4), 371-383. http://dx.doi.org/10.1080/07294360802406833

Pintrich, P. R. (2000). Multiple-goals, multiple pathways: The role of goal orientation in learning and $\begin{array}{lllll}\text { achievement. Journal of Educational Psychology, } & \text { 92, } & \text { 544-555. }\end{array}$ http://dx.doi.org/10.1037/0022-0663.92.3.544

Pintrich, P. R., Conley, A. M., \& Kempler, T. M. (2003). Current issues in achievement goal theory and research. International Journal of Educational Research, 39, 319-337. http://dx.doi.org/10.1016/j.ijer.2004.06.002

Raudenbush, S. W., \& Bryk, A. S. (2001). Hierarchical linear models: Applications and data analysis methods (2nd ed.). Newbury Park: Sage.

Schumacker, R. E., \& Lomax, R. G. (2004). A beginner's guide to structural equation modeling ( $2^{\text {nd }}$ ed.). Mahwah, NJ: Lawrence Erlbaum Associates, Inc.

Schunk, D. H., \& Zimmerman, B. J. (1998). Self-regulated learning: From teaching to self-reflective practice. New York: Guildford.

Senko, C., \& Miles, K. M. (2008). Pursuing their own learning agenda: How mastery-oriented students 
jeopardize their class performance. Contemporary Educational Psychology, 33, 561-583. http://dx.doi.org/10.1016/j.cedpsych.2007.12.001

Simons, J., Dewitte, S., \& Lens, W. (2004). The role of different types of instrumentality in motivation, study strategies, and performance: Know why you learn, so you'll know what you learn! British Journal of Educational Psychology, 74, 343-360. http://dx.doi.org/10.1348/0007099041552314

Sins, P. H. M., van Joolingen, W. R., Savelsbergh, E. R., \& van Hout-Wolters, B. (2008). Motivation and performance within a collaborative computer-based modeling task: Relations between students' achievement goal orientation, self-efficacy, cognitive processing, and achievement. Contemporary Educational Psychology, 33, 58-77. http://dx.doi.org/10.1016/j.cedpsych.2006.12.004

Skaalvik, E. M., \& Rankin, R. J. (1998). Self-concept, self-efficacy and achievement in mathematics: A test of causal relations. Paper presented at the Annual Meeting of the American Educational Research Association, San Diego, CA.

Skrondal, A., \& Rabe-Hesketh, S. (2004). Generalized latent variable modeling: Multilevel, longitudinal, and structural equation models. Boca Raton, FL: Chapman \& Hall/CRC. http://dx.doi.org/10.1201/9780203489437

Steiger, J. H. (1990). Structural model evaluation and modification: An interval estimation approach. Multivariate Behavioral Research, 25, 173-180. http://dx.doi.org/10.1207/s15327906mbr2502_4

Stipek, D. J., \& Kowalski, P. S. (1989). Learned helplessness in task-orienting versus performance-orienting test conditions. Journal of Educational Psychology, 81, 384-391. http://dx.doi.org/10.1037/0022-0663.81.3.384

Tanaka, A., \& Yamauchi, H. (2001). A model for achievement motives, goal orientations, intrinsic interest, and academic achievement. Psychological Reports, 88, 123-135. http://dx.doi.org/10.2466/pr0.2001.88.1.123

Urdan, T. (2004). Using multiple methods to assess students' perceptions of classroom goal structure. European Psychologist, 9(4), 222-231. http://dx.doi.org/10.1027/1016-9040.9.4.222

Urdan, T., Kneisel, L., \& Mason, V. (1999). Interpreting messages about motivation in the classrooms: Examining the effects of achievement goal structures. In T. Urdan (Ed.), Advances in motivation and achievement (Vol. 11). Stamford, CT: JAI.

Valle, A., Cabanach, R. G., Núñez, J. C., Gonnzález-Pienda, J., Rodríguez, S., \& Piñeiro, I. (2003). Multiple goals, motivation and academic learning. British Journal of Educational Psychology, 73, 71-87. http://dx.doi.org/10.1348/000709903762869923

Van Yperen, N. W., Elliot, A. J., \& Anseel, F. (2009). The influence of mastery-avoidance goals on performance improvement. European Journal of Social Psychology, 39, 932-943. http://dx.doi.org/10.1002/ejsp.590

Vansteenkiste, M., Simons, J., Lens, W., Soenens, B., \& Matos, L. (2004). Less is something more: Goal-content matters. Journal of Educational Psychology, 96, 755-764. http://dx.doi.org/10.1037/0022-0663.96.4.755

Walker, R. A., Pressick-Kilborn, K., Arnold, L. S., \& Sainsbury, E. J. (2004). Investigating Motivation in Context. European Psychologist, 9(4), 245-256. http://dx.doi.org/10.1027/1016-9040.9.4.245

Wolters, C. A. (2004). Advancing achievement goal theory: Using goal structures and goals orientations to predict students' motivation, cognition, and achievement. Journal of Educational Psychology, 96, 236-250. http://dx.doi.org/10.1037/0022-0663.96.2.236

Wolters, C. A., Yu, S. L., \& Pintrich, P. R. (1996). The relation between goal orientation and students' motivational beliefs and self-regulated learning. Learning and Individual Differences, 6, 211-238. http://dx.doi.org/10.1016/S1041-6080(96)90015-1

Zimmerman, B. J. (2002). Becoming a self-regulated learner: An overview. Theory Into Practice, 41, 64-72. http://dx.doi.org/10.1207/s15430421tip4102_2

Zimmerman, B. J., \& Risemberg, R. (1997). Self-regulatory dimensions of academic learning and motivation. In E. Phye (Ed.), Handbook of academic learning (pp. 105-125). New York: Academic Press. http://dx.doi.org/10.1016/B978-012554255-5/50005-3

Zimmerman, B. J., \& Schunk, D. H. (2001). Self-regulated learning and academic achievement: Theoretical perspective. Hillsdale, NJ: Erlbaum. 